\title{
Radio Constellation to Strengthening Local Identity
}

\author{
${ }^{1}$ ATIE RACHMIATIE, 2 DEY RAVENA, ${ }^{3}$ YENNI YUNIATI \\ 1,3 Fakultas Ilmu Komunikasi, Universitas Islam Bandung, Jl. Taman sari No 1, \\ 2 Pascasarjana Unisba, Jl Purnawarman No. 59 Bandung \\ email: ${ }^{1}$ atierachmiatie@yahoo.com, dey@unisba.ac.id
}

\begin{abstract}
A problem of broadcasting system in Indonesia, radio broadcasts in particular, lies in its insignificant contribution to strengthening the local identity, albeit the power of radio that is on the proximity of the media and its audiences. Local identity seems to fade away nowadays and being left behind by its community, whereas it has the power to shape the national identity, especially for young generation. This article examines a constellation of radio broadcasts in strengthening local identity. This study uses a qualitative method of case study with subject's research of private mainstream broadcast radio in West Java. The research result finds that institutional owners have difficulties to balance commercial interests and editorial side since the radio needs to go forward in the industry and gain profits, but on the other side is "chained" by prevailing regulations and idealism. This is the reason why radio needs to advance in technology, contents, and human resources and also follows the trends. Implementation on program/content of broadcast is based on the spirit to undertake the local potential, but the change in listeners' state demands the radio manager to transforms local culture in such a way to be accepted by those listeners. Contents are focused on values and characters, while the packaging remains the present. The dominance of media conglomeration in broadcasting industry hampered the development of local radio.
\end{abstract}

Keywords: Radio broadcasts, Media conglomeration, Local Identity

\section{Introduction}

At this time, the local cultural identity shares no place nor time in the mainstream media and has started to be abandoned by the ethnic holders. For example, the Sundanese language speakers have already reduced in great numbers; the Sundanese press decreased from 39 publishing to 8 publishing (Sumiati, 2015). While local art on television aired for only about $1 \%$. Result of researcher's observation on students in Bandung (urban) shows that younger generation in urban areas (of North Bandung) feel embarrassed to speak Sundanese because it is considered "tacky". This condition is of concern, because the language reflects the values, norms, or philosophy of wise living corresponds to eastern wisdom of good manners, ethics, etc. Other facts show that of the 10 national private television stations, $48 \%$ of broadcast source sent from Jakarta and its surrounding areas, $38 \%$ from regions outside Jakarta (divided from 33 provinces of Indonesia), and $7 \%$ of international means the average information from the province is only $1.15 \%$ (Remotivi and UNPAD, KPID Jabar in 2017).

Loss of local culture means missing the ethnical identities or nationalities, or the loss of Indonesian multicultural since the mass media in general do not keep such things in their broadcasts. Radio and television today further develop the mass culture. Whereas the position of broadcast media is very powerful, both to strengthen/preserving or rather weaken/remove the local culture.

One of the causes of current media's condition is due to media conglomeration or concentration of media ownership. Media industry is dominated by private broadcasters loaded with political or business interests, or both. Transformation in media sector, in fact, reflects the transition from "state regulation" to "market regulation"; where the media industry is not operated based on state intervention but primarily shaped by market mechanisms and determined by market forces (Mosco, 1996 in Hidayat 2003:5). Data from

Received: October 24, 2017, Revision: April 27, 2018, Accepted: June 04, 2018

Print ISSN: 0215-8175; Online ISSN: 2303-2499. DOI: http://dx.doi.org/10.29313/mimbar.v34i1.3159.93-101

Accredited B based on the decree No.040/P/2014, valid on February, 18, 2014 until February, 18, 2019. Indexed by DOAJ, Sinta, IPI 
Media Scene in 2013 showed that shopping ads on media was mainly used for political ads of 6.8 trillion Rupiahs.

Conceptually, the constellation/ state/order or, in other words, imaginable description of institutional-based radio broadcast dilemma can be seen in the model created by Ishadi SK (2014):

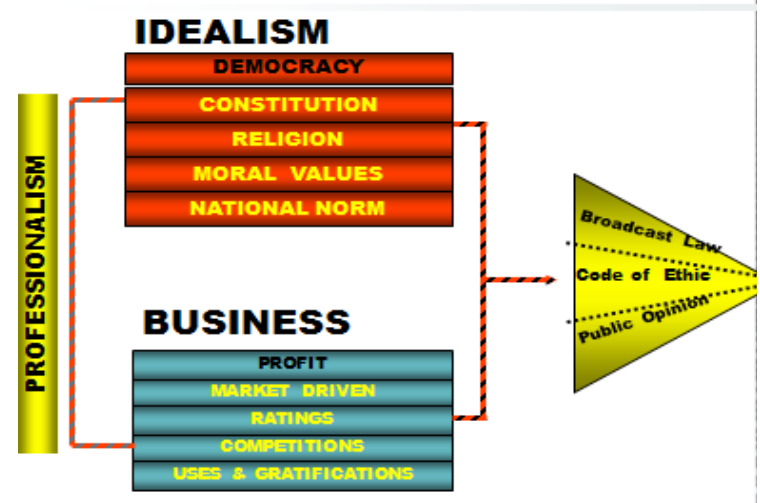

Figure 1 Business Interests and Model of Broadcasters (Ishadi SK)

The model illustrates that business interests and idealism in broadcast can be run in balance and harmony if they are framed by professionalism. In addition, all the aims and future goals intended by both ideologies can be reached if they refer to broadcasting law, code of ethics, and public opinion.

This research uses theory of political economy of the media to study the theme. It is a discipline of knowledge that have been developed since a long time and emerged as an approach to the development of capitalism. Critical political economic study has three main variants: instrumental, structuralist, and constructivist. On instrumental variant, the mass media are seen as instruments for the dominant class. Class of investors uses the power of market economy to ensure that the flow of public information goes in accordance with the vision and mission of their goals. Analysis of structuralist is likely to see the structure as something monolithic, well-established, static, and determinants. While constructivist analysis is a result of contradictions between instrumental analysis and structuralist. Constructivist sees the structure as something that is not yet perfect and moves dynamically. Whereas Mosco argues that economics-politics is a study of social relationships, especially relations of power which underlying the production, distribution, and consumption of resources (Mosco, 1996:25). Application of theory of political economy of the media in the lives of mass media is as follows: commodification, spatialization, and structuration with the explanation below:

Commodification is the process of changing goods and services with values to be transformed into commodities that are priced to what they could earn on market. Commodification deals with three domains, namely the realm of media content commodification, the realm of audiences' commodification, and the realm of labor commodification. The realm of media content commodification is an area of media messages with content that has value or economic value. The realm of audiences' commodification is an area where audience is considered as the main media commodity. A medium that managed to create a lot of audience members will have a high value and well appreciated by advertisers. Since the framework refers to audience as the market and content as the commodity, the chance of exploiting both sides is widely open. Product that can be sold in media industry usually concerns the content of entertainment or pop culture. The broadcast messages of entertainment and popular culture on local private radio take shape in forms of either national or western songs, or an interactive entertainment with popular culture themes. Such programs, surely, are debilitating efforts of strengthening local cultural values. Audience of private radio -mostly dominated by teenagers-are counted as market in accordance with the demands of economic interests of the media. The audience then sold to manufacturing industry with assumption that their characteristics matched the advertised product segmentation. The media gain profits from advertisers by providing time and space to be sold within radio programs..

Spatialization is a process of overcoming the barriers of space and time in social life. The technology developed and applied by mass media has enabled the processes of delivering the message through mass media and omitting the barriers of space and time. The convergence of media, as the integration of conventional media with internet network, is a technology product practiced by almost all mainstream media, including radio, to improve the quality and expand the range of broadcasting. This also resulted in a dependency of audience upon the media and cultivate a new culture which can be a threat to the strengthening process of local culture with regard to media consumption by public. 
Structuring is the process of shaping the structure in a major industry. The merging of several industries that support each other has created a huge profit in an efficient way. Kompas-Gramedia Group is an example of media industry convergence and owns several media such as TV 7 (television), Sonora FM Jakarta (radio), Salvatore FM Surabaya (radio), and the Bikima FM (radio). The impact of this convergence is efficiency in news material, ad networks, and collaboration with other institutions.

Factually at the moment, most of radio broadcast agencies in West Java have only the broadcasts programs and contents of entertainment functions. On the other hand, there are many broadcasters who are not professional and unqualified broadcast contents as well. There is no standardization of the requirements in recruitment pattern of announcers. The media ownership is loaded with personal, political, or business interests, whereas they are using the frequency of limited public sphere (Rachmiatie, 2016). The following described that component in broadcasting will be intertwined. Owners of capital generally have vision and characteristics that will affect human resources working in their institution, which then will affect managerial quality, quality programs and broadcast contents, which in turn will affect the knowledge, attitudes, consciousness and behavior of audience exposed to the media.

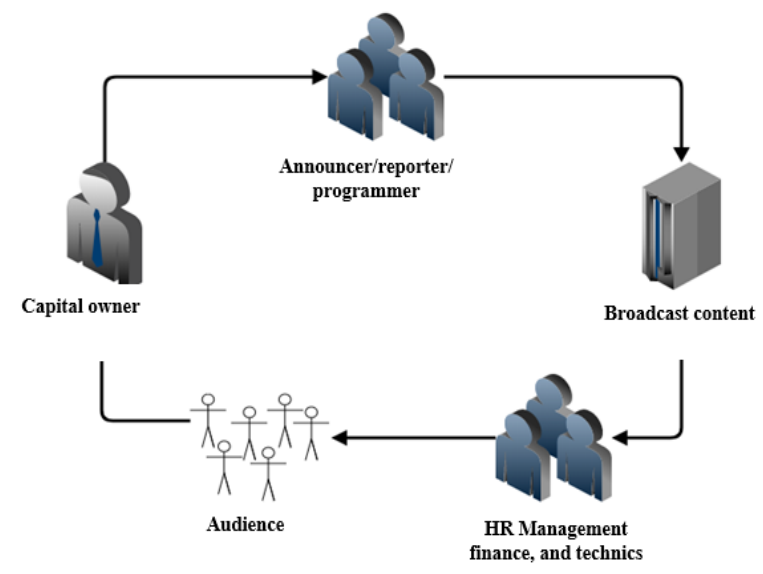

\section{Figure 2. The line of attachment of Radio Broadcast}

Globalization, information, and communication lead to changes on a national scale, regionally and locally in various aspects of life, including in the world of media broadcasting and other mass media. The contents of broadcast information from one country can be easily accepted by other countries via satellite. Similarly, the presentation of information is generally in convergence between one media and the others. There is a complete guidance in certain tabloid about radio or television broadcast that will be aired; or newspapers which can be read on the internet through online newspapers.

The occurrence of economic escalation is another change factor which affects the free trade, the intense competition in broadcasting industry, standards of quality, including the professional management of institutions. On the other hand, the progress of information and communication technology causes to many extensive changes, such as information formatting, forms of media technics (hardware), forms of presentation and shifting in media consumption patterns. These changes bring implications to the world of radio. Based on the research results by Media Scene (2014), it stated that West Java has the most radio and television broadcast in Indonesia, which are 468 private broadcasters, public broadcasting and broadcasting community with listeners of $3,488,000$ people. Viewing media penetration as a whole, it shows that television is the largest and number one media exposed to audience, and radio as the second largest in 9 major cities in Indonesia. The following is data from AC Nielsen reported in Media Scene, published in 2014 i.e: $94.1 \%$ of audience exposed to television, $21.1 \%$ exposed to radio, $20.3 \%$, to internet, $13 \%$ to newspapers, $12.1 \%$ to magazines and tabloids, and $0.7 \%$ to film/cinema (Media Scene, 2014).

A constellation of radio broadcasts compared to other mass media is still significant, i.e. radio penetration has reached $18.6 \%$ to $21.3 \%$ of teens and young adults' listener. Radio power lies on its proximity to listeners, its local elements, and the ability to form the "theater of the mind" in a much more powerful impression in the minds of listeners compared to television or other media. Therefore, radio broadcasts can actually be used to instill values that developed in the local community. On the other hand, in accordance with the development of media industry, a research by A. Rahim and Pawanteh (2010) found that local content is actually a potential profitable business that needs to be directed and supervised in the interest of the nation. "The potential for local content market to grow cannot be denied. However, its growth need to be monitored to ensure it does not stray from the nations aspirations. "Furthermore, 
the results of study presents the data that Malaysia wants to avoid local content with values, norms, and lifestyles that are contrary to the cultures they want to preserve and pass on to the next generation. Based on that reason Malaysia stipulates a rule that $75 \%$ of television contents should broadcast local content in their programs and shows, such as news, talk show, documentary, or entertainment. TV9 Malaysia even dedicates $72 \%$ of its broadcast programs for rural residents in Malaysia.

According to the above background, then the research problems being studied are: (a) How the radio constellations institutionally can balance commercial and editorial interests in strengthening local identity? (b) How does the process and implementation of local identity in the program and content of broadcast? c) What is the model of broadcast radio constellation in strengthening local culture?

\section{Research Methods}

This study uses qualitative methods with subjective paradigms and approach of case studies since there is no agreement yet among practitioners, regulators (KPI/D), academician, and public regarding local identity in radio broadcast. In addition, there is also contradiction between thoughts that local content is not profitable and only for the benefit of public, and the thought of local content as profitable commodity for the media. This condition is unique to be examined and in line with the pluralistic nation of Indonesia which until today have not yet found a standard and an exact indicator of the "nation identity." The data obtained through interview techniques (depth interview) and focus group discussion (FGD) to the owner, manager, and private radio programmer in West Java represented by mainstream radio, i.e. established radio with large scope of audience and turnover of 17 private radios combined.

\section{The Balance of Commercial Interests \& Editorial}

In carrying out the programs and shows, the manager of radio broadcasts has idealism that can not be separated from various economic or political interests. Managers have a high interest in something, even hobbies and said "my soul is already on the radio " (Yoni of Purwakarta Radio, and Reza of Ardan Radio, 2017). It means the "idealism" in the form of ethical values and norms, ideas, visions, and work orientation in radio coloring their actions in their daily work life.

Some of private radio managements turned out to have similar management of those community broadcasters, in which their spirit is not merely a business profit, but also satisfaction/non-financial benefits earned by managers. But certainly, the "spirit of voluntarism" should remain to be owned by private radio managers, though, being in the midst of very unhealthy broadcasting industry's competition. This is in accordance with the statement of Schroender in Lilis Dede (2016: 82):

Volunteers are individuals willing to donate labour or service, capabilities, without expecting any material gain from service organizations to organize a particular activity formally. Volunteers are in charge of serving others, providing many benefits and goodness to many parties and people, such as public health, social ties were tightened, increasing the confidence (trust) and the norms of reciprocity in the community without expecting to get rewards and compensation.

On the other hand, radio broadcast should also refer to broadcasting regulations of Broadcasting Act number 32/2002, Government Regulation (Perppu) and The Regulation of Minister of Communication

Tabel 1

List of Research Informants

\begin{tabular}{lllc}
\hline No & \multicolumn{1}{c}{ Character of Radio } & \multicolumn{1}{c}{ Name of Radio } & Total \\
\hline 1 & Urban Radio (young generation) & 99 Ners, Ardan, Shelter, I-Radio, Thomson & 4 \\
2 & Ethnic Radio & Ray, ABG, Flamboyan, Sadang, Pasundan & 5 \\
3 & Dangdut Radio & Dahlia, Garuda, Megaswara & 3 \\
4 & Family Radio & Lita FM & 1 \\
5 & News Radio & PR FM, Sindo Trijaya & 2 \\
6 & Islamic Radio & MQ Radio & 1 \\
& Total & & 17 \\
\hline
\end{tabular}


and Information, which stated that network broadcasters are required to serves local broadcast at least $10 \%$ in all of their broadcasting. These regulations are made due to current trend of many broadcasters have a concentrated media ownership, thus forming radio networks with "branches" in local areas. Although the rule on the liability of network broadcaster only requires $10 \%$ of local content, it is factually difficult to be implemented so that local content broadcast is allocated outside the "prime time", that is in the middle of the night or at dawn when audiences are not listening to the radio. Study on culture/indigenous knowledge/local identity has not yet done completely by actors of radio broadcast, local government, or even by Central Broadcasting Commission though.

Institutionally, implementation of local identity in the program and content of broadcast is inseparable from the support of external broadcasters. Research findings based on interviews and focus group discussion reveal that Law number $32 / 2002$ on Broadcasting is considered sufficient to regulate the broadcast, but the implementation has not been consistent yet, especially related to the cross-ownership that should be limited. Such conditions encourage people to have dozens of media broadcasting, print media, online media, and other media industry which make a media with massive capital becoming increasingly strong and control the market with its "pop culture" commodity that gain a high rating. Whereas local broadcast media which has a very little capital is in a worse condition and should struggle to broadcast with the leftover "ad pie". For example, the case of radio network Radio Thomson FM and Sindo/ FM Trijaya with their master/central radio in Jakarta. They said their radios have the same vision and mission as their masters' and wanted to work based on regulation/law and applying $10 \%$ of local content. But in reality, it was not something easy to do. Fortunately they have programs in Sundanese language that play Sundanese songs according to the given portion. But outside of those programs, they use Indonesian language with a similar program nationwide. That is one of their efforts to uplift and maintain local content. (Aldi, 2017)

Subsequently, to lift up local potential as a local identity in West Java, radio manager and owner need support from local government who have the same vision to uplift the community of West Java with its culinary potential, creative industries, natural tours, etc. However, in fact, support from local government for radio broadcasters is not optimal. It is felt by manager of Radio Ardan who said, "As a media, we were required to have the desire to develop local culture and content. However, on the one hand, that local culture we want to raise is not supporting us back. For example, we always broadcast the activities of city government of Bandung, and the government aware that radio is a stakeholder in West Java, but we haven't received an appropriate appreciation. This is an example of a case that recently happened. There was a staff of local government who came to me ordering to down our radio tower in Lembang because they will build the hotel or shopping center in that area. I was surprised, why did they do that for? Our radio is one of the spearheads/key radios for Bandung government to socialize their programs. Here I talk about mutual relationship. On the one hand, we have to comply with government rules, but on the other hand, the government applied arbitrarily action toward us. This situation needs to be resolved since the radio was set up by the government and there are myriad of rules. Broadcasting the election ad is another case example. Election ad or campaign broadcasting that hold once in 5 years should be limited to 15 days. They failed to understand that the moment of election/campaign is the moment to gain income because surely there are many representatives of the people want to do the campaign. But this did not happen. Instead, the Commission subjectively chose the certain radio they want to cooperate with (whoever is closer to them). Moreover, there is a new media of internet. It is not monitored and tightly regulated as KPID did to the radio. Based on those cases and my experience, I hope there is a FGD with government to find solutions or the need to create a new policy that is mutually beneficial.

These conditions are in accordance with the explanations of Rachmiatie \& Suryadi (2014:24) that, "The broadcasting policy in Indonesia has not been established yet due to the government changing policy the political systems, social culture, and especially the ongoing economic system. Before the reform era, it seemed that all broadcasting media policy boils down to the interests of government with Ministry of Information that controlled the print and broadcast media. In the era of reform and post-reform, the country began to lose control of power over three 
major elements namely civil society, market, and media." This condition led to the strong concentration of ownership and they have power to control information presented to the public. More tragically, the owners of current media conglomerates are also leaders of the parties that control the media and capable of affecting the draft regulation, so that public interest as the real owner of the frequency is being overlooked.

Broadcasting Regulation is also related with government policy or commitment of public officials alike to have an awareness of the importance of preserving local culture and identity. When it does not become a "political will" of the leaders, ethnic identity or the identity of our nation will be faded, eroded by foreign cultures which bombard young generation like a tsunami." Yoni $\mathrm{AH}$, a senior radio manager and chairman of ARSLI (Association of Indonesian Private Local Radio) points out: "I want to tell you a little about Purwakarta. It is a region rich of culture. Unfortunately, when I see the Regent to discuss about the local culture of Purwakarta, there was no meaningful response. So basically, almost all radios in Purwakarta heralded the local culture, but when they held a meeting on local culture, the local government did not present. To be honest, most of the radios in Purwakarta have local content." Actually, there is an interesting finding from the research of Supriadi \& Herdono (2016: 289) about local culture in TV9 of East Java. The management of TV-9 since the beginning has been "declared" as a television of dakwah (Islamic preach), capable of sustaining local culture which is implemented as its highlight TV program, namely Religi Islam (Islamic religion). Other finding is their success in maintaining local culture. It can not be separated from management' constancy to commit their true identity as a religious television amid the fierce of other mainstream televisions. This condition is in line with radio broadcasts management who have commitment to raise the rich local potential in West Java by managing and packaging local identities in such a way that it remains worthy of sale and make profits.

The following figure describes how radio broadcaster institutionally balancing the idealism with order of regulation that requires local identity representation as a social responsibility of broadcasting media toward public. On the other side, it is the broadcasting industry that demands the manager to reap enormous profits to be able to maintain and develop the institution.

\section{Process and Implementation of Local Identity in Radio Broadcast Program and Content}

Local identity which is implemented in programs and radio broadcast vary greatly depending on the broadcaster or radio programmers in each radio. PR FM, for example, created a highlight program of local potential by reporting traffic and latest situation in Bandung. Shelter FM Radio, Cirebon uplifts the art of Batik Cirebon in a variety of products, in accordance with its presence in the midst of batik Center "Trusmi". Ardan FM Radio bring in young figures of Bandung to talk about the excellence and give positive motivation to young urban listeners. Radio in Cianjur Regency, Purwakarta, Majalengka, and Greater Bandung lift up the genre of art, culinary, and sights spots to attract their listeners.

The owners of the radios classified as ethnic radio, i.e. Ray FM Cirebon, ABG FM, Flamboyant FM, Sadang FM, and Pasundan FM state that local identity is lifted from public/audiences condition, in which some are relatively homogeneous and others are ethnically heterogeneous. Purwakarta and Cianjur, as "central" of Sundanese culture, have a high level of Sundanese language with their distinctive arts of Cianjuran music and others. That is why events and shows held are adapted specifically to circumstances and tastes of their audiences/listeners. It is in contrast to programs and events involving a heterogeneous community, such as Cirebon Java, Sundanese or Minangkabau which also provided by radios in the area. Ray Radio does not aim its broadcast specifically to particular ethnic because the manager has already committed that Cirebon is the city of transit and welcome all kinds of people from any culture to listen and enjoy the programs. This radio is not only used Sundanese in the introduction, but combining it with Indonesian Language to reach and captive greater audience comprising people of different tribes, not only Sundanese or Javanese. Managers want the broadcast to hit all listeners. Ray Radio has multisegment audiences and divided its programs into: Pop song of $50 \%$ and dangdut song of $50 \%$ which divided again to ethnic song (Sundanese-Javanese or Tarling) of $35 \%$ and dangdut of $15 \%$. Based on experience, to uplift the existed 


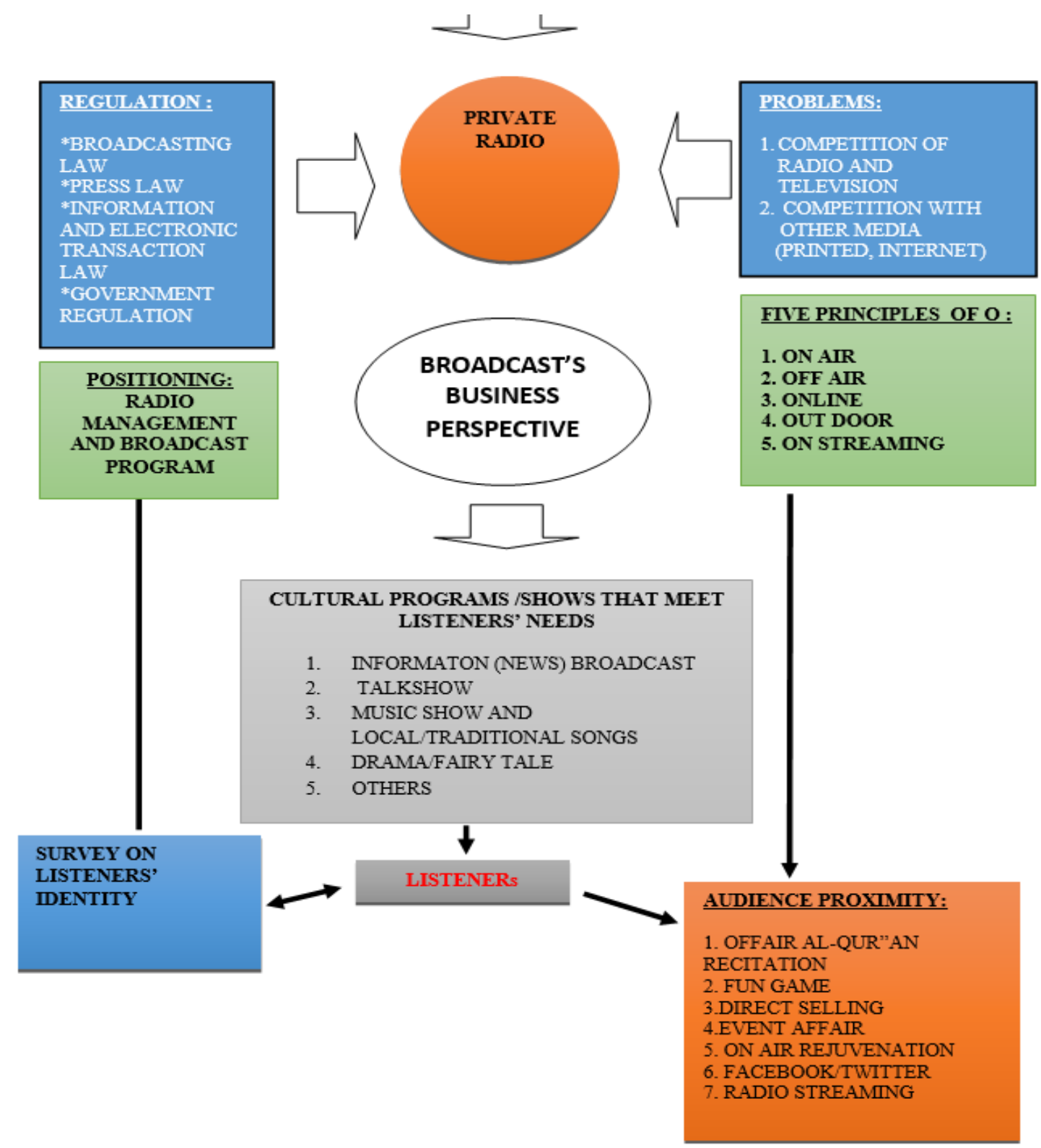

Figure 3. Radio Constellation Institutionally to Strengthening Local Identity

community, Ray FM held programs such as live karaoke (listeners gathered each week on radio), paguyuban pendengar (listeners' club) as regular show, also paguyuban Batak, paguyuban Pop (youth) and paguyuban semua (all Club) (Enaldi h. Shah, 2017).

In contrast to the above statement, Thomson as the manager of radios representing urban areas of Bandung, namely Ardan FM, 99 Ners Radio, I-Radio, states: "We focus to young and teens listeners only since those radios aimed at young people. In my opinion, first, young people are easily influenced by technology, especially social media. They are well aware that they are the descendants of Sunda tribe or others, but they are trying to identify themselves as young generation in the present or "I am a young people today". They compete to follow the trend because if they don't they would be left behind. From the company side, there is a local program because we should keep and conserve Sundanese culture. Although we do not have special program on Sundanese culture (since the radio aimed for young people), but in delivering the broadcast the announcers are allowed to use Sundanese language. Second, in terms of information. the information presented on the radio should contain local content. It is mandatory. Why? Because national or international content is not that much and local content takes the largest portion of broadcast. We think that portion for national and international content 
concluded that institutional radio constellation in order to balance commercial interests and editorial is considered a difficult choice because radio owners face a dilemma of going forward in the industry' and get profit, and on the other hand, is "chained" by prevailing regulations and idealism as the demands of the community. This is the reason why radio should transform in technology, content, human resources and follow the demands of the times. Process and implementation of local identity in program and broadcast content is based on spirit of managers to carry out and uplift the local identity. It is just that the change of taste and interest of listeners demanding radio broadcast manager to create transformation of local culture that will be accepted by listeners. Local identity focuses to values and character, but wrapped in the packaging of present day. Factor of industrial system and macroeconomy are not yet supporting the development of radio media fairness and impartiality to local area. On the other side, the political economy of media is dominating the broadcasting industry tremendously and influences the development of local radios in obtaining "cakes ads". The low quality of human resources in broadcasting, including announcers, programmers, technicians, and marketers has put a weak position of bargaining in dealing with concentrated media ownership. Whereas this industry is unique for its capability to combine commercial and idealism in a balanced way. In the future, it is necessary to follow-up studies that analyze constellations of broadcast radio in a comprehensive way, especially on public and community radio. Indonesian Broadcasting Commission (KPI/ KPID) can enforce regulation consistently and fairness with a favour to local broadcast radio to grow, maintain, and even build local wisdom and cultural/religious identity and nation. Radio broadcasts can accommodate all demographic segments in the presentation of broadcast program and content. Practically, Private Radio Association (PRSSNI) and the HRD of broadcasting (broadcasters, programmers, technicians, marketers) need to improve the quality of themselves, referring to the ethical profession and more professional by improving themselves through various training, courses, seminar that add insight, knowledge, and skills as employees of the radio.

\section{References}

A. Rahim Samsudin \& Pawanteh Latiffah, (2010), The Local content industry and cultural identity in Malaysia. Jurnal of Media and Communication Studies Vol.2 (10), Desember 2010. ISSN 2141-2545@ 2010 Academic Journals.

Dede Lilis, at all, (2016), Voluntarism as Social Capital of Commuity Radio Management: a case studi in Jarik III Cirebon, Komunitas, International Journal of Indonesian Society and Culture, Vol 8 number 1 March 2016, ISSN p-20865465/e-ISSN 2460-7320, Semarang.

Dedy N Hidayat, (2003). Paradigma dan Metodologi Penelitian Sosial Empirik Klasik. Jakarta: Fakultas IImu-IImu Sosial Universitas Indonesia.

Ishadi SK, (2014), Media \& Kekuasaan, Televisi di hari-hari terakhir presiden Soeharto, Penerbit Kompas, Jakarta.

Komisi Penyiaran Indonesia Daerah Jawa Barat, (2017), "Mengawal Penyiaran Menyelamatkan Generasi Muda" KPID Jabar, Bandung.

Media scene: The Official Guide to Advertising media in Indonesia, (Volume 25, 20132014) Jakarta.

Media scene: The Official Guide to Advertising media in Indonesia, (volume 26, 20152016) Jakarta.

Mosco Vincent, (1996). The Political Economy of Communication Rethinking and Renewal. SAGE Publication.

Rachmiatie Atie \& Suryadi, Karim. (2014), Sistem \& Kebijakan Komunikasi Penyiaran di Indonesia. Bandung: Komisi Penyiaran Indonesia Daerah Jawa Barat (KPID Jabar)

Rachmiatie, Atie dkk, (2016). Konstelasi Radio dalam Mewujudkan Budaya/Identitas Lokal, perspektif regulasi dan teori ekonomi politik Media, Laporan Penelitian, Hibah Dikti, LPPM UNISBA Bandung.

Sumiati, Neti Hasandinata, Pers Berbahasa Sunda dari masa ke masa, (2015), Penerbit Granesia, 57-76.

Supriadi \& Herdono, Ismoyo, (2016), Strategi TV-9 Dalam Mempertahankan Budaya Lokal (Kajian dari Perspektif Manajemen Penyiaran), Proceeding CSGPSC, Strengthening Local Communities Facing the Global Era, Aspikom.

Suyanto, Edy,. Dkk, (2017), Social Engineering on Mangrove Preservation Based on Fishermen's Local Wisdom, Jurnal Mimbar, Jurnal Sosial dan Pembangunan, Volume 33, no.1 (Juni 2017), ISSN 0215-8175, Unisba Bandung. 
is better conveyed by other media, such as newspapers and television. We usually take headlines from other media for national and international content. Local contents are off air-events, PENSI (Performance Art) of school children, covering the activities of the Mayor, and so on. While in the on-air program, there should be Sundanese language as a twist. Coverage of Identity/culture/local wisdom is not purely ethnic regional, but should also involve today's trend, such as covering the Mayor, culinary tour, and so on. Ardan Radio management obliges the crew to wear batik at particular moment. However, there is no obligation to speak Sundanese all the time since this is not the era to speak only Sundanese. But young people should remain well aware of Sundanese cultural values in West Java as his ancestor's legacy that should be maintained and conserved. (Reza S, 2017).

To keep their listeners with them, urban radios need to do the transformation in packaging, format, shape, and presentation. It would also give them a high rating and get an adequate "cakes ads". In the midst of competition with foreign cultures, such as "K-POP" (Korea), China, America, Japan, which permeates the halls of the mind and heart of our young people, it is certainly a conflict of dynamic to receive the traditional culture as their identity. On the one hand, foreign cultural is greatly exposed to young generation through attractive packaging, while on the other hand, exposure to local culture is very rare and less shown or presented in mainstream media. Such imbalance in flow of information change the mindset, attitudes, and behaviors of young people today. They tend to ignore religious values, eastern philosophy values, and Pancasila. For example, there is a tradition back in the days where people pray first before eat, but young people now would take a picture of the food first before they eat and "upload" it in social media. It takes a strategy and "Political will" in order to keep our local identity alive in the society, especially for young people. Research by Suyanto et. al., (2017) offers patterns of social engineering in the preservation of local wisdom in his study of "Social Engineering on Mangrove Preservation Based on fishermen's Local Wisdom". His findings prove that, each community in Indonesia has local wisdom, particularly in Kampung Laut, Segara Anakan, which have myths and traditions that actually formed the basis of the knowledge and attitude of its citizens to live in harmony with the environment. It would take social engineering with reference to local wisdom to resolve similar problem.

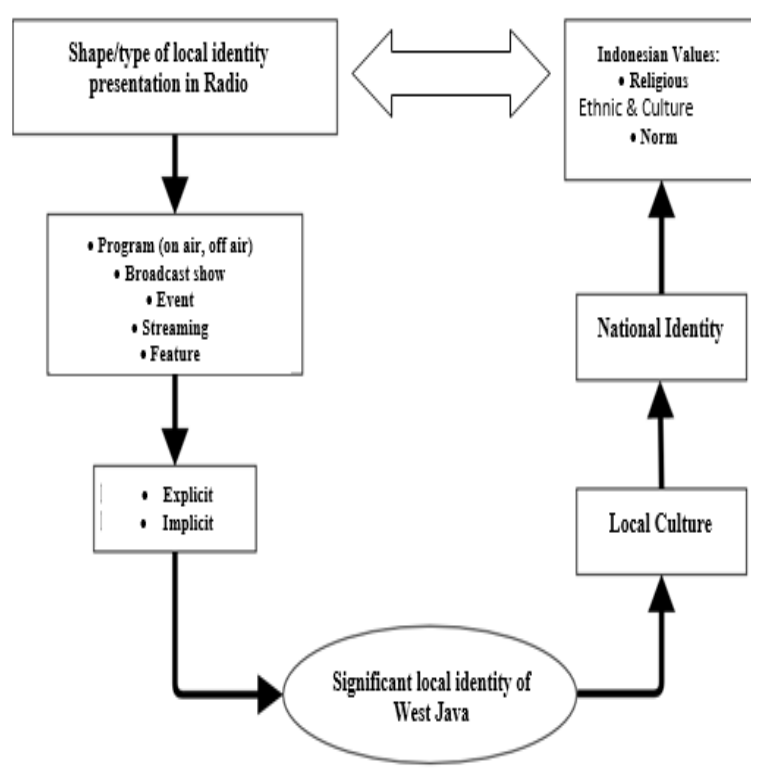

Figure 4: The Cycle of Radio Broadcast Implementation in Strengthening Local Identity

Similar conditions can be imposed by broadcasting media to the condition of society in West Java which has values, norms, and behavior patterns oriented to Islam primarily religious or in rich cultural rituals and traditions. It is in accordance with the role and functions of the radio broadcasting (Broadcasting Law of 23/2002) which stated that broadcast media serve the information, education, entertainment, social control, as well as to advance the culture to be optimal. There are various selection of packaging for programs and events of radio broadcasts since radio power lies on its "proximity" to listeners and also the voice that can form a "Theatre of the Mind", in addition to flexibility and mobility of use. However, in addition to commitment of the owners and leaders, it is necessary to have professional human resources (HR) in broadcast production, marketing, finance, and also reliable technicians. With the power of internal HR and support from institutional and external factors such as regulation and local government, mainstream radio broadcast can play an optimal role to uplifting and strengthening local identity of West Java community. The following is description of implementation cycle of radio broadcasts in strengthening local identity.

\section{Conclusion}

Based on previous discussion, it is 